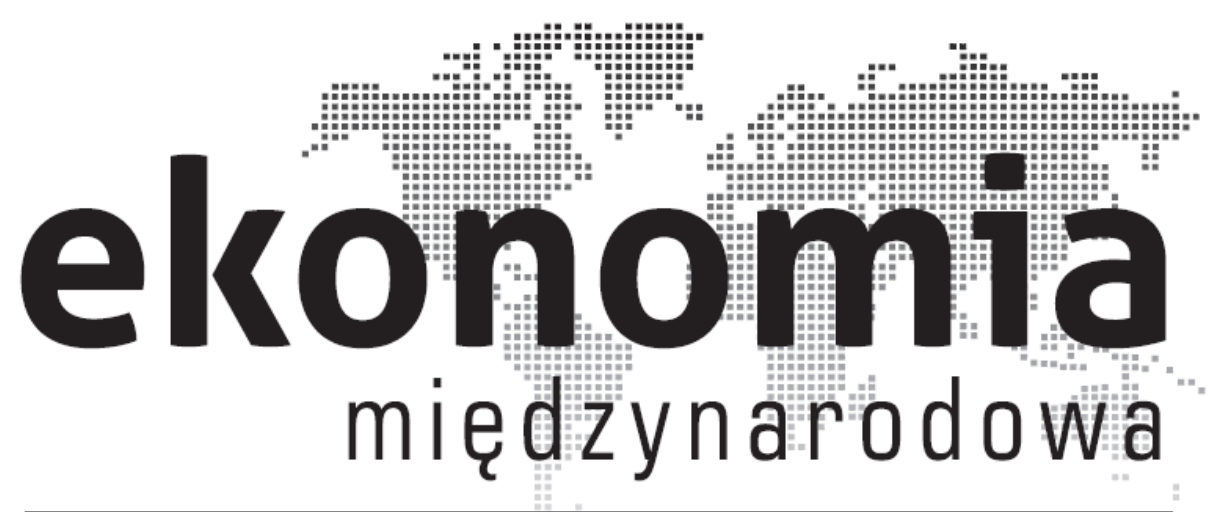

Ekonomia Międzynarodowa

Nr 14 (2016)

Wydawca: Uniwersytet Łódzki

(Publisher: University of Lodz)

www.ekonomia-m.pl

ISSN: 2082-4440 - wydanie papierowe (paper edition)

ISSN: 2300-6005 - wydanie elektroniczne (electronic edition)

Wersja elektroniczna czasopisma jest wersją referencyjną

(Electronic edition is the reference version of the journal)
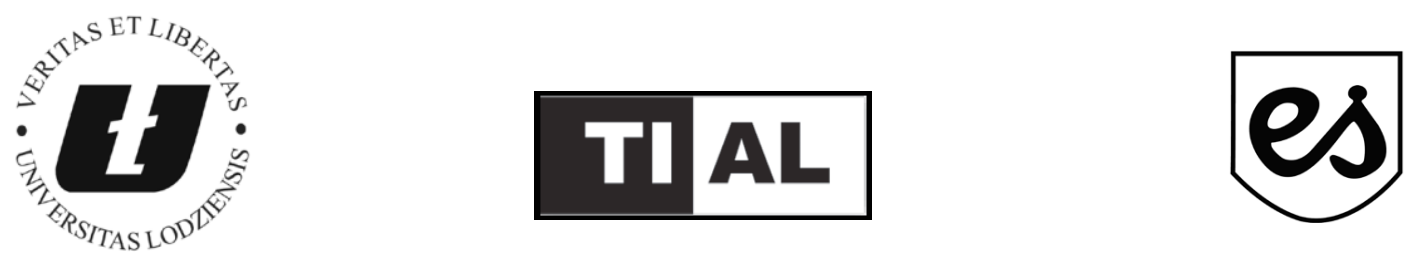


\section{Wpływ środków pomocowych z Unii Europejskiej na kondycję gospodarczą Polski w latach 2007-2013}

Monika Śliwka*

\section{Wstęp}

Pomoc finansowa z Unii Europejskiej była, jest i będzie istotnym czynnikiem rozwoju polskiej gospodarki. Dzięki niej sfinansowano szereg inwestycji i projektów w bardzo wielu obszarach społeczno-gospodarczych.

W artykule przedstawiono wielkość i strukturę środków unijnych, które trafiły do Polski w latach 2007-2013, oraz zsynchronizowano je z okresem finansowania zaplanowanym na lata 2014-2020. Zostaną wskazane również główne obszary wykorzystywania funduszy pochodzących z Unii Europejskiej. Istotną częścią będą próba oszacowania wartości inwestycji finansowanych ze środków Unii Europejskiej oraz przykłady najważniejszych przedsięwzięć. Następnie wyniki badań nad wielkością i strukturą inwestycji finansowanych ze środków unijnych zostaną wykorzystane do analizy udziału środków pomocowych z Unii Europejskiej i środków krajowych w finansowaniu inwestycji w Polsce. Kolejna część to ocena wpływu środków unijnych na kondycję polskiej gospodarki w latach 2007-2013, nawiązująca do kryzysu gospodarczego, który miał miejsce w Europie. W artykule skupiono się na polityce spójności, nie uwzględniano środków pomocowych dla rolnictwa, ze względu na specyfikę tego sektora, i sposobu dofinansowania środkami UE; warto podjąć ten temat w innym artykule.

Problem badawczy polega na wyodrębnieniu najważniejszych przedsięwzięć możliwych do zrealizowania dzięki środkom z Unii Europejskiej oraz wskazaniu głównych obszarów wykorzystywania funduszy pozyskanych ze Wspólnoty. Metody zastosowane do badania i oceny projektu to badanie literatury oraz źródeł pochodzących z internetu.

\footnotetext{
*Monika Śliwka - studentka ekonomii, SKN „Arystoteles”, Politechnika Świętokrzyska.
} 


\section{Wielkość i struktura środków pomocowych z UE}

Wspólnota Europejska zaczęła pomagać Polsce już na przełomie lat 80. i 90. XX w. za pomocą programu PHARE. W późniejszym czasie, przed wstąpieniem do Unii Europejskiej, Polska czerpała środki pomocowe z programów SAPARD i ISPA (Aulak M. i in. 2004, s. 5). Pełne korzystanie z funduszy europejskich było możliwe po przystąpieniu Polski do Unii Europejskiej. Środki pomocowe pozyskane z UE w latach 2007-2013 miały istotny wpływ na rozwój polskiej gospodarki oraz na jej integrację z gospodarkami pozostałych państw członkowskich. Unia Europejska udziela wsparcia finansowego na realizację wielu różnych projektów i programów w dziedzinach takich jak:

1. rozwój regionalny,

2. zatrudnienie oraz integracja społeczna,

3. rolnictwo i rozwój obszarów wiejskich,

4. polityka morska i polityka rybołówstwa,

5. badania naukowe oraz innowacje,

6. inwestycje infrastrukturalne,

7. wsparcie sektora MSP.

Polska znajduje się teraz na etapie podsumowywania okresu finansowania 2007-2013, który przyniósł wiele korzyści zarówno w skali mikro, jak i makro. Kolejnym etapem rozwoju kraju jest zainwestowanie funduszy zaplanowanych na lata 2014-2020. Podobnie jak w ubiegłych latach Polska jest największym beneficjentem funduszy unijnych. Po uchwaleniu przez Parlament Europejski budżetu UE na lata 2014-2020 Polska może liczyć na 105,8 mld euro, z czego ponad 72,9 mld zostanie przeznaczone na politykę spójności ${ }^{1}$ (Fundusze Unijne w latach 2014-2020, 2015), a 28,5 mld euro na politykę rolną (Parlament Europejski przyjąt budżet..., 2015).

Lata 2007-2013 zaowocowały w przypadku Polski dofinansowaniem i rozdysponowaniem kwoty w wysokości około 102 mld euro (Dziś Parlament Europejski zatwierdzit budżet..., 2013); 68,2 mld euro pochodziło z Europejskiego Funduszu Rozwoju Regionalnego, Europejskiego Funduszu Społecznego oraz Funduszu Spójności (EU Funds in Central and Eastern Europe. Progress Report 2007-2014, 2015, s. 44 ). W ramach podziału funduszy między kraje Europy Centralnej oraz Wschodniej Polska otrzymała aż 38,2\% budżetu unijnego przeznaczonego na dofinansowanie państw tego regionu. Dla porównania - Czechy otrzymały $14,9 \%$, a Rumunia $10,9 \%$ tych środków. W ramach budżetu unijnego na lata 2014-2020 środki finansowe przyznane Polsce, czyli około 82,3 mld euro, będą wdrażane na podstawie programów operacyjnych zarządzanych zarówno na poziomie krajowym, jak i na poziomie regionalnym (EU Funds in Central and Eastern Europe. Progress Report 2007-2014, 2015, s. 44 ):

1. Program Operacyjny Infrastruktura i Środowisko (około 27,41 mld euro);

2. Program Operacyjny Inteligentny Rozwój (około 8,61 mld euro);

\footnotetext{
${ }^{1}$ Po przeliczeniu z cen stałych na bieżące - około 82,3 mld euro.
} 
3. Program Operacyjny Wiedza, Edukacja, Rozwój (około 4,69 mld euro);

4. Program Operacyjny Polska Cyfrowa (około 2,17 mld euro);

5. Program Operacyjny Polska Wschodnia (około 2 mld euro);

6. Program Operacyjny Pomoc Techniczna (około 0,7 mld euro);

7. 16 Regionalnych Programów Operacyjnych (około 31,28 mld euro);

Porównanie środków z budżetu unijnego (w ramach polityki spójności) dla Polski w latach 2007-2013 oraz w latach 2014-2020 przedstawia rysunek 1.

Wykres 1. Środki przyznane Polsce przez Unię Europejską na realizację polityki spójności (w mld euro)

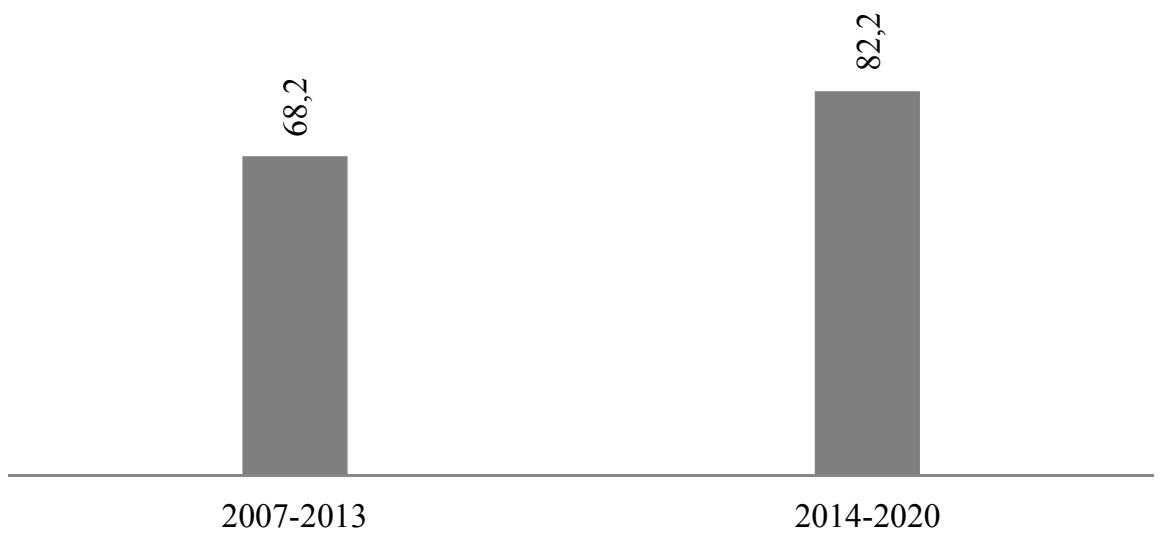

Źródło: opracowanie własne na podstawie: Fundusze Unijne w latach 2014-2020, PKO Bank Polski (2015), www.pkobp.pl/korporacje-i-samorzady/fundusze-unijne/fundusze-unijne-w-latach-2014 -2020/fundusze-unijne-w-latach-2014-2020 (data dostępu: 02.07.2015); EU Funds in Central and Eastern Europe. Progress Report 2007-2014, KPMG, (2015), www.kpmg.com/PL/pl/IssuesAndInsights/ArticlesPublications/Documents/2015/EU-Funds-in-Central-and-Eastern-Europe -2007-2014.pdf, s. 44 (data dostępu: 02.07.2015).

Jak wynika z rysunku, wsparcie w latach 2007-2013 było mniejsze niż to, które Polska otrzymuje od roku 2014. Umożliwia to przeprowadzenie większej liczby inwestycji. Wsparcie unijne to ogromna szansa dla polskiej gospodarki. Kraj został niemalże wyróżniony, otrzymując zaufanie, jeśli chodzi o powierzone mu środki unijne.

\section{Główne obszary inwestycji i efekty wykorzystania funduszy pochodzących z Unii Europejskiej}

Główne obszary, w których dokonywano alokacji funduszy Unii Europejskiej, oraz efekty ich wykorzystania określono na podstawie informacji udostępnionych przez Ministerstwo Infrastruktury i Rozwoju (Efekty Funduszy Europejskich, 2015). 
W dziedzinie technologii informacyjnych również nastąpił znaczny rozwój dzięki wpływowi środków pomocowych z Unii Europejskiej - Polska wzbogaciła się o $55799 \mathrm{~km}$ sieci szerokopasmowego internetu. Dla współczesnej cywilizacji ważnym czynnikiem jest dostęp do internetu, dlatego położono duży nacisk na rozwijanie infrastruktury teleinformatycznej w Polsce za pomocą środków Unii Europejskiej. W dobie społeczeństwa informacyjnego branża IT powinna być rozwijana bardzo dynamicznie. Inwestycje w tym obszarze umożliwiły również powstanie 5817 nowych e-usług.

Najbardziej charakterystycznym i zauważalnym obszarem, jeśli chodzi o absorpcję funduszy Unii Europejskiej, jest infrastruktura komunikacyjna. Wybudowano $11472 \mathrm{~km}$ dróg krajowych, wojewódzkich, powiatowych i gminnych. Zmodernizowano lub zbudowano łącznie $1670 \mathrm{~km}$ linii kolejowych, a także zakupiono lub zmodernizowano 2638 jednostek taboru komunikacji miejskiej.

W ostatnich latach w Europie i na świecie niezwykle istotna jest ochrona środowiska. Szczególny nacisk położono na inwestycje w zbiorcze i przydomowe oczyszczalnie ścieków. Dzięki środkom unijnym wybudowano 504 oczyszczalnie oraz zmodernizowano lub wybudowano $24285 \mathrm{~km}$ sieci wodociągowych. Bardzo ważną kwestią są również odnawialne źródła energii, w zakresie których dzięki dotacjom podjęto 723 inwestycje. Przeprowadzono także 1793 działania związane ze zwiększaniem efektywności energetycznej.

Istotną kwestią jest wykorzystywanie środków ze względu na rodzaj beneficjentów. Zaliczają się do nich organy administracji rządowej, uczelnie oraz jednostki naukowe, organizacje non profit, przedsiębiorstwa, jednostki samorządu terytorialnego (JST) oraz inne jednostki. Największą pulę środków otrzymały przedsiębiorstwa - $92581 \mathrm{mln}$ zł, czyli 32\% łącznej kwoty przeznaczonej na realizację polityki spójności (Wykorzystanie środków UE w ramach ..., 2015). Na drugim miejscu znajdują się jednostki samorządu terytorialnego - $88655 \mathrm{mln}$ zl, 31\%. Dane dotyczące podmiotów, które otrzymały środki Unii Europejskiej w Polsce, oraz wartość tych środków przedstawiono w tabeli 1.

Tabela 1. Udział beneficjentów w środkach unijnych w Polsce oraz wielkość pomocy UE

\begin{tabular}{|l|c|c|}
\hline Beneficjenci & Dane w mln zł & Struktura \\
\hline Organy administracji rządowej & $65346 \mathrm{zl}$ & $23 \%$ \\
\hline JST & $88655 \mathrm{zl}$ & $31 \%$ \\
\hline Uczelnie, jednostki naukowe & $23009 \mathrm{zl}$ & $8 \%$ \\
\hline Organizacje non profit & $9497 \mathrm{zl}$ & $3 \%$ \\
\hline Przedsiębiorstwa & $92581 \mathrm{zl}$ & $32 \%$ \\
\hline Inne & $7133 \mathrm{zl}$ & $3 \%$ \\
\hline
\end{tabular}

Źródło: Wykorzystanie środków UE w ramach Narodowej Strategii Spójności 2007-2013. Informacja miesięczna za kwiecień 2015 r., Ministerstwo Infrastruktury i Rozwoju, (2015), www.mir.gov.pl/ media/4239/NSRO_miesieczna_kwiecien_2015.pdf(data dostępu: 06.07.2015). 


\section{Wartość inwestycji finansowanych ze środków Unii Europejskiej w latach 2007-2013}

Trudno jednoznacznie oszacować wartość inwestycji finansowanych ze środków UE, głównie ze względu na ich ciągłą realizację oraz trwający proces podsumowywania perspektywy finansowej 2007-2013. Jednym z instrumentów polityki spójności są Regionalne Programy Operacyjne, przypisane do danego województwa. Dzięki takim inwestycjom nastąpiła poprawa atrakcyjności inwestycyjnej Polski i jej regionów, rozwinęła się także infrastruktura techniczna. Środki unijne wpłynęły też na poprawę stanu środowiska naturalnego oraz ochrony zdrowia. Można stwierdzić, że fundusze UE przyczyniły się do rozwoju społeczno-gospodarczego Polski. Wartość inwestycji w ramach RPO prezentuje tabela 2.

Tabela 2. Liczba i wartość złożonych wniosków, podpisanych umów oraz wniosków o płatność w ramach RPO

\begin{tabular}{|l|c|c|c|c|}
\hline \multirow{2}{*}{ Województwa } & Regionalne Programy Operacyjne \\
\hline & $\begin{array}{c}\text { Liczba wniosków } \\
\text { o dofinans. po } \\
\text { ocenie form. }\end{array}$ & $\begin{array}{c}\text { Liczba umów } \\
\text { o dofinans. }\end{array}$ & $\begin{array}{c}\text { Wydatki } \\
\text { kwalifikowane } \\
\text { w tys. PLN }\end{array}$ & $\begin{array}{c}\text { Dofinans. UE } \\
\text { w tys. PLN }\end{array}$ \\
\hline dolnośląskie & 3572 & 2284 & 7492854 & 4625316 \\
\hline kujawsko-pomorskie & 3615 & 2270 & 5347712 & 3211465 \\
\hline lubuskie & 1825 & 1009 & 2971887 & 1773707 \\
\hline lódzkie & 4148 & 2417 & 5636076 & 3767691 \\
\hline lubelskie & 5569 & 3122 & 6464462 & 4213274 \\
\hline mazowieckie & 6166 & 2280 & 8957860 & 6328106 \\
\hline małopolskie & 4512 & 2977 & 8082061 & 4941817 \\
\hline opolskie & 1931 & 1200 & 3037702 & 1964178 \\
\hline podlaskie & 2560 & 1266 & 3698913 & 2244872 \\
\hline podkarpackie & 3633 & 2577 & 6672860 & 4556365 \\
\hline pomorskie & 3670 & 1711 & 5357315 & 3460674 \\
\hline śląskie & 9325 & 4992 & 9022120 & 6252544 \\
\hline świętokrzyskie & 2026 & 1289 & 4813074 & 2921118 \\
\hline warmińsko-mazurskie & 3800 & 2487 & 5994797 & 3811999 \\
\hline wielkopolskie & 4444 & 2373 & 7133439 & 4640103 \\
\hline zachodniopomorskie & 3085 & 1722 & 4727892 & 2877771 \\
\hline razem & 63881 & 35976 & 95411025 & 61590999 \\
\hline
\end{tabular}

Źródło: Wykorzystanie środków UE w ramach Narodowej Strategii Spójności 2007-2013. Informacja miesięczna za kwiecień 2015 r., Ministerstwo Infrastruktury i Rozwoju (2015), www.mir.gov.pl/ media/4239/NSRO_miesieczna_kwiecien_2015.pdf (data dostępu: 06.07.2015). 
Najwięcej przedsięwzięć ze środków UE sfinansowano w województwie mazowieckim. Wielkość dofinansowania wyniosła tam $6328,1 \mathrm{mln}$ zł. Najmniej środków w ramach RPO trafiło do województwa lubuskiego - $1773,7 \mathrm{mln}$ zł.

Dane z kwietnia 2015 wskazują, że w latach 2007-2013 wpłynęło 63881 wniosków o dofinansowanie w ramach Regionalnych Programów Operacyjnych dla województw, a liczba umów dofinansowanych wyniosła 35 976. Wartość dofinansowania z UE to $61590,999 \mathrm{mln}$ zł, a poziom alokacji RPO wyniósł $86 \%$ (Wykorzystanie środków UE w ramach..., 2015).

Kolejnym kwestią jest ocenienie wartości inwestycji przeprowadzonych dzięki dotacjom z UE w ramach pozostałych programów operacyjnych obejmujących obszar całego kraju. Były to: Program Operacyjny Innowacyjna Gospodarka, Program Operacyjny Infrastruktura i Środowisko, Program Operacyjny Kapitał Ludzki, Program Operacyjny Pomoc Techniczna, Program Operacyjny Rozwój Polski Wschodniej oraz Program Operacyjny Europejska Współpraca Terytorialna.

Szczegółowe dane dotyczące poziomu dofinansowania w ramach wymienionych programów przedstawia tabela 3 .

Tabela 3. Liczba i wartość złożonych wniosków, podpisanych umów oraz wniosków o płatność w ramach krajowych programów operacyjnych

\begin{tabular}{|l|c|c|c|c|}
\hline \multirow{2}{*}{$\begin{array}{l}\text { Nazwa } \\
\text { Programu }\end{array}$} & $\begin{array}{c}\text { Liczba wniosków } \\
\text { o dofinans. } \\
\text { po ocenie } \\
\text { formalnej }\end{array}$ & Liczba umów & \multicolumn{2}{|c|}{ Wnioski o płatność } \\
\cline { 4 - 5 } & 47466 & 17948 & 50544773 & 28215051 \\
\hline PO IG & 4449 & 3282 & 129348653 & 98462135 \\
\hline PO IS & 184297 & 47691 & 47249064 & 39396392 \\
\hline PO KL & 461 & 449 & 2154078 & 1830966 \\
\hline PO PT & 455 & 310 & 9879441 & 7741395 \\
\hline PO RPW & 655 & 311 & 1322529 & 1098866 \\
\hline PO EWT & 237793 & 69991 & 240498538 & 176744804 \\
\hline razem & & Wydatki kwalifik. & $\begin{array}{c}\text { Dofinans. UE } \\
\text { w tys. PLN }\end{array}$ \\
\hline
\end{tabular}

Źródło: opracowanie własne na podstawie Wykorzystanie środków UE w ramach Narodowej Strategii Spójności 2007-2013. Informacja miesięczna za kwiecień 2015 r., Ministerstwo Infrastruktury i Rozwoju, (2015), www.mir.gov.pl/media/4239/NSRO_miesieczna_kwiecien_2015.pdf (data dostępu: 06.07.2015).

Wielkość dotacji przeznaczonych na programy krajowe wyniosła 176 744,8 mln zł, a koszty kwalifikowane projektów - 240 498,5 mln zł. Największa część środków Unii Europejskiej w tym zakresie została przeznaczona na sfinansowanie inwestycji w ramach Programu Operacyjnego Infrastruktura i Środowisko. Projekty o wartości blisko 130 mld zł zostały dofinansowane z budżetu UE kwotą blisko 
98,5 mld zł. Szczególnym programem, jeśli chodzi zarówno o starania o dofinansowanie, jak i samo dofinansowanie, był Program Operacyjny Rozwój Polski Wschodniej (PO RPW). Był to program wsparcia dla pięciu województw: lubuskiego, podlaskiego, podkarpackiego, świętokrzyskiego oraz warmińsko-mazurskiego. Środki w ramach PO RPW przeznaczano na rozwój innowacyjnej przedsiębiorczości, inwestycje w komunikację miejską, drogi, kolej, a także na inwestycje ważne dla spójności i dostępności terytorialnej makroregionu. Najniższy poziom dofinansowania cechował Program Operacyjny Europejska Współpraca terytorialna (bez EISP), w ramach którego przedsięwzięcia dofinansowano kwotą blisko 1,1 mld zł.

$\mathrm{W}$ tabeli 4 przedstawiono łączny poziom dofinansowania unijnego w ramach programów regionalnych i lokalnych.

Tabela 4. Liczba i wartość złożonych wniosków, podpisanych umów oraz wniosków o płatność w ramach programów regionalnych i krajowych

\begin{tabular}{|l|c|c|c|c|}
\cline { 2 - 5 } \multicolumn{1}{c|}{} & $\begin{array}{c}\text { Liczba wnio- } \\
\text { sków o dofi- } \\
\text { nans. po oce- }\end{array}$ & Liczba umów & \multicolumn{2}{|c|}{ Wnioski o płatność } \\
\cline { 4 - 5 } & nie formalnej & & $\begin{array}{c}\text { Wydatki } \\
\text { kwalifik. } \\
\text { w tys. PLN }\end{array}$ & $\begin{array}{c}\text { Dofinans. UE } \\
\text { w tys. PLN }\end{array}$ \\
\hline Progr. regionalne & 63881 & 35976 & 95411025 & 61590999 \\
\hline Progr. krajowe & 237793 & 69991 & 240498538 & 176744804 \\
\hline Razem & 301674 & 105967 & 335909563 & 238335803 \\
\hline
\end{tabular}

Źródło: opracowanie własne na podstawie: Wykorzystanie środków UE w ramach Narodowej Strategii Spójności 2007-2013. Informacja miesięczna za kwiecień 2015 r., Ministerstwo Infrastruktury i Rozwoju (2015), www.mir.gov.pl/media/4239/NSRO_miesieczna_kwiecien_2015.pdf (data dostępu: 06.07.2015).

Wydatki kwalifikowane na inwestycje finansowane z udziałem środków Unii Europejskiej wyniosły około 335 909,6 mln zł. Dofinansowanie do tej kwoty w skali całego kraju oraz wszystkich omówionych programów to 238 335,8 mln zł.

\section{Najważniejsze przedsięwzięcia i inwestycje}

Najważniejsze przedsięwzięcia realizowane w Polsce w latach 2007-2013 dzięki dotacji Unii Europejskiej można podzielić na kilka podstawowych obszarów: nauka i edukacja, energetyka, transport, turystyka, bezpieczeństwo, badania i rozwój, kultura i sztuka, ochrona zdrowia, rozwój przedsiębiorstw, telekomunikacja i rozwój e-usług, praca i integracja społeczna, współpraca międzynarodowa, administracja i ochrona środowiska. Jako przykłady można podać (Zobacz jak Polska..., 2015): 
1. Rozbudowa infrastruktury dydaktycznej Uniwersytetu Jana Kochanowskiego w Kielcach - II etap budowy Campusu Uniwersyteckiego;

2. Budowa i modernizacja Wydziałów Biologii, Fizyki i Chemii Uniwersytetu Łódzkiego;

3. Centrum Naukowo-Dydaktyczne Wydziału Inżynierii i Kształtowania Środowiska - „Centrum Wodne” SGGW;

4. Termomodernizacja obiektów użyteczności publicznej na terenie powiatów: białogardzkiego, drawskiego, kołobrzeskiego, koszalińskiego, szczecineckiego i świdwińskiego;

5. Podziemny Magazyn Gazu Strachocina;

6. Budowa drogi ekspresowej S3, odcinek Gorzów Wlkp. - Nowa Sól, na odcinku Gorzów Wlkp. - Sulechów;

7. Modernizacja i rozwój zintegrowanego systemu transportu zbiorowego w Olsztynie;

8. Przebudowa drogi krajowej $\mathrm{nr} 1 \mathrm{w}$ granicach administracyjnych miasta Włocławek;

9. Przebudowa ul. gen. St. Maczka w Białymstoku;

10. Arena Ostróda, Centrum Targowo-Konferencyjne Warmii i Mazur;

11. Budowa przystani jachtowej w Sopocie;

12. Grunwald - zespół działań inwestycyjno-remontowo-konserwatorskich i muzealnych związanych z kompleksowym zagospodarowaniem Pól Grunwaldzkich;

13. Doposażenie bazy sprzętowej kompanii powodziowej Kujawsko-Pomorskiej Wojewódzkiej Brygady Odwodowej Państwowej Straży Pożarnej - w ugrupowaniu ewakuacyjnym;

14. Zakup pojazdu ratowniczo-gaśniczego z funkcją ratownictwa ekologicznego dla jednostki krajowego systemu ratowniczo-gaśniczego OSP Malanów;

15. Rozbudowa infrastruktury naukowo-badawczej Politechniki Rzeszowskiej;

16. Elbląski Park Technologiczny na Modrzewinie-Południe;

17. Budowa i uruchamianie nowych obiektów Parku Naukowo-Technologicznego Polska - Wschód w Suwałkach;

18. Budowa Centrum Nauki „Kopernik” w Warszawie;

19. Dziedzictwo Chopina na Szlaku Traktu Królewskiego w Zamku Ostrogskich w Warszawie;

20. Renowacja Teatru Starego w Lublinie;

21. Modernizacja taboru ambulansów ratunkowych w Świętokrzyskim Centrum Ratownictwa Medycznego i Transportu Sanitarnego w Kielcach;

22. Budowa lądowiska dla helikopterów w Regionalnym Szpitalu Specjalistycznym w Grudziądzu;

23. Uruchomienie linii produkcyjnej wykorzystującej technologię druku bezwodnego firmy Toray Industries;

24. Rozwój klastra informatycznego firm wschodniej Polski; 
25. Stworzenie internetowego serwisu wspomagającego odnajdywanie osób zagubionych oraz zagrożonych utratą zdrowia lub życia;

26. Serwis do budowania mobilnych społeczności w oparciu o komunikację SMS;

27. Wsparcie osób niewidomych na rynku pracy;

28. Stworzenie otwartej strefy rekreacji dziecięcej na potrzeby uczniów OSW dla Dzieci Niewidomych w Owińskach oraz mieszkańców powiatu poznańskiego;

29. Eurojob Viadrina - Poprawa perspektyw zawodowych i edukacyjnych oraz mobilności w Euroregionie Pro Europa Viadrina;

30. Modernizacja drogowej infrastruktury komunikacyjnej Ostrunia - granica państwa - Niedzica;

31. Dwie Cerkwie - zbliżenie kultur pogranicza Polski i Słowacji;

32. Kreowanie markowych produktów turystycznych Małopolski Południowej w oparciu o doświadczenia partnerów sieci Town Twinning;

33. Kompleksowa rewaloryzacja Parku Północnego w Sopocie - etap I.;

34. Zakład Przetwarzania Odpadów Komunalnych regionu chełmskiego i rekultywacja składowisk odpadów;

35. Budowa sieci kanalizacyjnej na terenie Aglomeracji Komarowo - miejscowości Załom, Pucice, Rurzyca.

Wymienione inwestycje obrazują, jak duży wpływ na gospodarkę Polski miały fundusze unijne. Pozwoliły one na rozwój i postęp techniczny całego kraju.

\section{Udział środków pomocowych z Unii Europejskiej i środków krajowych w finansowaniu inwestycji (kosztów kwalifikowanych) w Polsce}

Jednym z warunków dofinansowania środkami Unii Europejskiej części projektów było wniesienie udziału własnego do inwestycji. Na wkład własny składały się zarówno środki zabezpieczone na ten cel w budżecie państwa, jak i kapitał prywatnych inwestorów.

Polska w okresie dotacyjnym 2007-2014 była największym wśród państw członkowskich beneficjentem funduszy unijnych. Unia Europejska pokryła polskim podmiotom $71 \%$ kwalifikowanych kosztów różnego rodzaju inwestycji, $29 \%$ w tej strukturze stanowił wkład własny. Udział funduszy Unii Europejskiej w postaci programów operacyjnych w strukturze kosztów kwalifikowanych był różny. Dofinansowanie UE w przypadku Regionalnych Programów Operacyjnych stanowiło około 64,6\% kosztów kwalifikowanych RPO, a krajowe programy operacyjne charakteryzowały się 73,5-procentowym poziomem pokrycia tych kosztów środkami pochodzącymi z Unii Europejskiej. 


\section{Ocena wpływu środków unijnych na kondycję polskiej gospodarki w latach 2007-2013}

Unijne środki pomocowe miały, mają i najprawdopodobniej będą mieć istotny wpływ na polską gospodarkę. Należy podkreślić, że przyczyniły się do powstania wielu nowych przedsiębiorstw, instytucji otoczenia biznesu, do wdrożenia licznych rozwiązań technologicznych czy restrukturyzacji zakładów przemysłowych. Wpłynęły one na koniunkturę gospodarczą, konsumpcję oraz stabilizację finansową przedsiębiorstw. Na uwagę zasługuje polska innowacyjność, finansowana głównie z PO IG. Niedostateczna realizacja celów, takich jak zwiększenie innowacyjności przedsiębiorstw, wzrost konkurencji i zwiększenie udziału polskich produktów innowacyjnych na rynku międzynarodowym, stawia pod znakiem zapytania przyszłość tej dziedziny w Polsce (Osuch-Rak E. 2014, s. 212-213). W Narodowych Strategicznych Ramach Odniesienia 2007-2013, które są podstawowym dokumentem realizacji polityki spójności w Polsce (Narodowe Strategiczne Ramy Odniesienia 2007-2013, 2007), zakładano w tym okresie zmiany stopy wzrostu $\mathrm{PKB}^{3}$.

Dzięki środkom unijnym podejmowano w Polsce liczne inwestycje, nawet w czasie kryzysu gospodarczego. Taka sytuacja umożliwiła zatrudnienie wielu pracowników, w tym osób bezrobotnych. Wkład funduszy Unii Europejskiej, jeśli chodzi o dynamikę PKB Polski w latach 2007-2013, przedstawiono w tabeli 5.

Tabela 5. Dynamika funduszy UE w porównaniu z dynamiką PKB w Polsce [p.p.]

\begin{tabular}{|l|c|c|c|c|c|c|c|}
\hline Rok & 2007 & 2008 & 2009 & 2010 & 2011 & 2012 & 2013 \\
\hline $\begin{array}{l}\text { Wpływ funduszy UE } \\
\text { na PKB }\end{array}$ & 0,7 & $-0,9$ & 1,4 & $-0,7$ & 0,6 & 0,4 & $-0,8$ \\
\hline
\end{tabular}

Źródło: Kwartalnik Ekonomiczny. Analizy Makroekonomiczne, Bank PKO BP (2014), www.dm. pkobp.pl/media_files/ba66e749-c340-4747-a57c-91da1678cf50.pdf (data dostępu: 06.07.2015).

Wahania wpływu funduszy Unii Europejskiej na dynamikę PKB można tłumaczyć ogólnymi wahaniami PKB. Amplituda wahań, zobrazowana za pomocą danych w tabeli 5, przekracza 2 p.p. w 2009 r. w stosunku do roku 2008. Zauważalne są naprzemienne wzrosty i spadki wpływu funduszy UE na dynamikę PKB.

Do realizacji celów związanych z obniżaniem stopy bezrobocia, podnoszeniem kwalifikacji zawodowych, zdobywaniem wykształcenia i nabywaniem umiejętności wykorzystywany był głównie Program Operacyjny Kapitał Ludzki. Stopa bezrobocia kształtowała się na poziomie 11,2\% w 2007 r., w 2008 r. stopa bezrobocia spadła do poziomu 9,5\%. Od tego czasu miał miejsce wzrostowy trend tego wskaźnika w 2013 r. stopa bezrobocia była równa 13,4\% (Obszary tematyczne, 2015). W latach 2007-2013 nastąpił wzrost bezrobocia o ponad 2 p. p., jednak można wysnuć

\footnotetext{
${ }^{3}$ Model HERMIN, założenie wpływu środków UE na realizację NSRO na poziomie około $95 \%$.
} 
wniosek, że bez funduszy Unii Europejskiej poziom tego zjawiska byłby o wiele wyższy, szczególnie w kontekście kryzysu gospodarczego. Fundusze Europejskie przyczyniły się do złagodzenia skutków kryzysu gospodarczego w polskim przemyśle i w polskiej gospodarce.

\section{Podsumowanie}

Na podstawie wyników badań przedstawionych w artykule można wysnuć następujące wnioski. Środki unijne stanowią istotne wsparcie dla polskiej gospodarki i są podstawą jej stabilnego rozwoju. Napływ środków pomocowych z Unii Europejskiej do Polski w postaci funduszy unijnych był, jest i najprawdopodobniej będzie jednym $\mathrm{z}$ najważniejszych efektów towarzyszących przystąpieniu naszego kraju do UE. W latach 2007-2013 zdecydowanie zwiększył się zasób finansowy na realizację projektów sektorów publicznego i prywatnego. Polska była w tym okresie programowania największym beneficjentem środków pomocowych UE spośród wszystkich nowo przyjętych państw członkowskich Unii. Na podstawie literatury oraz źródeł pochodzących z internetu przeprowadzono badania, dzięki którym można wysnuć wniosek, że dotacje te były ważnym źródłem finansowania niekiedy wielomilionowych inwestycji. W Polsce ułatwiono dostęp do nowych technologii i wprowadzono procedury ułatwiające komercjalizację wiedzy. Z funduszy unijnych skorzystało również społeczeństwo, głównie z projektów realizowanych w ramach PO KL. Główne wskaźniki ekonomiczne okresie 2007-2013 wykazywały tendencję spadkową, szczególnie z powodu kryzysu gospodarczego. Jednak brak środków pomocowych z budżetu unijnego prawdopodobnie wywołałby bardziej drastyczne i negatywne skutki gospodarcze. Perspektywa finansowa 2014-2020 powinna cechować się rozwiązaniami wypracowanymi na podstawie poprzedniej „siedmiolatki”.

\section{Bibliografia}

Aulak M. i in. (2004), Mapa pomocy Unii Europejskiej udzielonej Polsce w ramach programu Phare 1990-2003, ISPA 2000-2003 oraz SAPARD, Urząd Komitetu Integracji Europejskiej, https://polskawue.gov.pl/files/Dokumenty/ Publikacje_o_UE/publikacja_mapa_pomocy_UE.pdf, s. 5 (data dostępu: 02.07. 2015).

Dziś Parlament Europejski zatwierdzit budżet UE na lata 2014-2020, Strategia rozwoju województwa podlaskiego do roku 2020 (2013), www.strategia.wrotapodlasia.pl/pl/Aktulanosci/dzis_parl_euro_zatw_budz.htm (data dostępu: 02.07.2015).

Efekty Funduszy Europejskich, Ministerstwo Infrastruktury i Rozwoju (2015), www.mir.gov.pl/strony/zadania/fundusze-europejskie/wykorzystanie-i-efek- 
ty-funduszy-europejskich/fundusze-europejskie-na-lata-2007-2013/efektyfunduszy-europejskich (data dostępu: 02.07.2015).

EU Funds in Central and Eastern Europe. Progress Report 2007-2014, KPMG

(2015), www.kpmg.com/PL/pl/IssuesAndInsights/ArticlesPublications/ Documents/2015/EU-Funds-in-Central-and-Eastern-Europe-2007-2014.pdf (data dostępu: 02.07.2015).

Fundusze Unijne w latach 2014-2020, PKO Bank Polski (2015), www.pkobp.pl/korporacje-i-samorzady/fundusze-unijne/fundusze-unijne-w-latach-2014-2020/ fundusze-unijne-w-latach-2014-2020 (data dostępu: 02.07.2015).

Fundusze Unijne 2014-2020 w Polsce, Roedel \& Partner (2015), www.roedl. com/pl/pl/uslugi/doradztwo_w_zakresie_pomocy_publicznej/fundusze unijne_2014_2020_w_polsce.html\#header_anker (data dostępu:02.07.2015).

Kwartalnik Ekonomiczny. Analizy Makroekonomiczne, Bank PKO BP (2014), www.dm.pkobp.pl/media_files/ba66e749-c340-4747-a57c-91da1678cf50. pdf (data dostępu: 06.07.2015).

Ministerstwo Rozwoju Regionalnego (2007), Narodowe Strategiczne Ramy Odniesienia 2007-2013, Ministerstwo Rozwoju Regionalnego, Warszawa.

Obszary tematyczne, Główny Urząd Statystyczny (2015), http://stat.gov.pl (data dostępu: 02.07.2015).

Osuch-Rak E. (2014) Polska polityka innowacyjna - co nam dała Unia Europejska? [w:] Latoszek E., Stępnik A. (red.) 10 lat czlonkowstwa w Unii Europejskiej. Ocena i perspektywy, Wydawnictwo Uniwersytetu Gdańskiego, Gdańsk, s. 212-213.

Parlament Europejski przyjąt budżet na lata 2014-2020, Forbes (2013), www. forbes.pl/parlament-europejski-przyjal-budzet-na-lata-2014-2020, artykuly,166753,1,1.html (data dostępu: 02.07.2015).

Wykorzystanie środków UE w ramach Narodowej Strategii Spójności 20072013. Informacja miesięczna za kwiecień $2015 \mathrm{r}$., Ministerstwo Infrastruktury i Rozwoju (2015), www.mir.gov.pl/media/4239/NSRO_miesieczna_ kwiecien_2015.pdf (data dostępu: 02.07.2015).

Zobacz, jak Polska zmieniła się dzięki Funduszom Europejskim, Mapa Dotacji UE (2015), www.mapadotacji.gov.pl (data dostępu: 10.07.2015).

\section{Streszczenie}

Napływ środków pomocowych z Unii Europejskiej do Polski w postaci funduszy unijnych był, jest i najprawdopodobniej będzie jednym z najważniejszych efektów towarzyszących przystąpieniu naszego kraju do UE. Środki pomocowe z Unii Europejskiej w latach 2007-2013 miały wpływ na rozwój polskiej gospodarki oraz na jej integrację z gospodarkami pozostałych państw członkowskich.

Cel artykułu to przedstawienie wielkości i struktury środków unijnych, które trafiły do Polski w latach 2007-2013, a także głównych obszarów wykorzystania 
funduszy pochodzących z Unii Europejskiej. Ważną część badań stanowi próba oszacowania wartości inwestycji finansowanych ze środków UE oraz przedstawienie przykładów najważniejszych przedsięwzięć. Wyniki badań nad wielkością i strukturą inwestycji finansowanych ze środków unijnych zostaną wykorzystane do analizy udziału środków pomocowych z Unii Europejskiej i środków krajowych w finansowaniu inwestycji w Polsce, a także do oceny wpływu środków unijnych na kondycję polskiej gospodarki w latach 2007-2013, z uwzględnieniem kryzysu gospodarczego w Europie.

Weryfikacja sposobu oraz stopnia, bezpośredniego i pośredniego, oddziaływania funduszy UE na sytuację gospodarczą w Polsce pozwoli na ocenę wykorzystania środków pomocowych z perspektywy czasu oraz na synchronizację z nowym okresem programowania 2014-2020.

Słowa kluczowe: Unia Europejska, ekonomia, Polska, dotacje, kryzys gospodarczy, inwestycje

\section{Summary}

The impact of aid funds from the European Union on the condition of the Polish economy in 2007-2013

The influx of aid from the European Union to Poland in the form of EU funds was, is and probably will be one of the most important effects associated with our country's accession to the EU. The aid measures obtained from the European Union in 2007-2013 influenced the development of the Polish economy and its integration with the economies of other Member States.

This article presents the size and structure of the EU funds that went to Poland in 2007-2013. It will also indicate the main areas of use of the funding from the European Union. An important aspect of the research will attempt to estimate the value of investments financed from EU funds and to provide examples of major projects. The results of research on the size and structure of investment projects financed from EU funds will then be used to analyze the share of aid from the European Union and national funds in financing investment in Poland as well as to assess the impact of EU funds on the condition of the Polish economy in 2007-2013 with reference to the economic crisis which took place in Europe.

By verifying the methods and the extent of the direct and indirect impact of EU funds on the economic situation in Poland, we will assess the use of aid from the perspective of time and synchronization with the new programming period 2014-2020.

Keywords: The European Union, economics, Poland, grants, economic crisis, investments

JEL: F15, F10 